\title{
FUNDAMENTAL RIGHTS OF PEOPLE WITH DISABILITIES REFLECTED IN THE SOCIAL DISCOURSE OF THE MAIN DISABILITY ORGANISATIONS IN SPAIN
}

\section{ISMAEL LÓPEZ-CEPEDA}

ismaellopezcepeda@ucm.es

Marketing and Publicity Degree professor. PhD candidate in Audiovisual Communication and Advertising Doctoral Program at the Complutense University of Madrid (Spain). Member of the project "Visual map of professional orientation for the Degree in Advertising and Public Relations" at the Complutense University of Madrid.

LUIS MAÑAS-VINIEGRA Imanas@ucm.es

Professor in the Department of Applied Communication Studies at Complutense University of Madrid (Spain). He holds a PhD in Audiovisual Communication and Advertising with Extraordinary Award from the same University. His research interests include the management of intangibles in

Communication

\section{HIPÓLITO VIVAR-ZURITA}

hvivar@ucm.es

Professor of Information Technologies and Audiovisual Communication at the Complutense University of Madrid (Spain). Director of the research group FONTA (Training in New Audiovisual Technologies) officially recognized by the UCM. Currently I direct as Principal Investigator the national project 'Inclusion and Employment of people with disabilities in the audiovisual sector'

(COMPENSA).

\section{Abstract}

Ever since the United Nations Convention on the Rights of Persons with Disabilities took place in 2006, the promotion of fundamental rights for this group has been continuous, fostering social inclusion to reduce the stereotypes and prejudices that had prevailed until that time. The aim of this research is to analyse the discourse on social networks of the main associations, foundations, as well as public and private organisations with regard to disability in Spain on the International Day of Persons with Disabilities 2020, in order to identify the topics that generate the highest level of interaction among the different profiles on social networks. The results suggest that despite the limited reach of these organisations on social networks, their discourse is based on fundamental rights such as participation and inclusion, accessibility, individual autonomy, and equal opportunity, which provide greater knowledge and a positive vision of persons with disabilities to society as a whole, raising awareness about stereotypes, prejudices and hate speech that are still common.

\section{Keywords}

Disability, Human rights, Social media, Inclusion, Accessibility.

\section{How to cite this article}

López-Cepeda, Ismael; Mañas-Viniegra, Luis; Vivar-Zurita, Hipólito. Fundamental rights of people with disabilities reflected in the social discourse of the main disability organisations in Spain. Thematic dossier International Relations and Social Networks, July 2021. Consulted [online] on date of last visit, https://doi.org/10.26619/1647-7251.DT21.7

Article received on December24, 2020 and accepted for publication on February 23, 2021

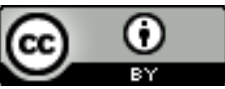




\section{FUNDAMENTAL RIGHTS OF PEOPLE WITH DISABILITIES REFLECTED IN THE SOCIAL DISCOURSE OF THE MAIN DISABILITY ORGANISATIONS IN SPAIN ${ }^{12}$}

ISMAEL LÓPEZ-CEPEDA

LUIS MAÑAS-VINIEGRA

HIPÓLITO VIVAR-ZURITA

\section{Introduction}

The Convention on the Rights of Persons with Disabilities (United Nations, 2006) was a milestone in the struggle against the exclusion suffered by people with disabilities within the UN human rights system, even though its recognition in subsequent agreements has only sometimes been comprehensive, often limited to formal statements (Skarstad and Stein, 2018). Today, there continues to be a clash between personal identity and the social construction of disability (Tsatsou, 2020). Stigma, discrimination, and social exclusion of this group has been continual from the point of view of societal aspects, health, transport, housing, education, employment, and public services, as well as the negative image transmitted through the media (Oliver, 2004).

Recognition of the social model of disability has allowed us to move beyond medical circumstances affecting people with disabilities to focus on the social, political, legal and attitudinal experiences affecting people with disabilities, which require a greater understanding of justice (Riddle, 2020). Although people with disabilities are now recognised beyond their disability, a stronger social model is needed to enable people with disabilities to prosper and be more active in order to change society and its values, to uphold the dignity of the lives of people with disabilities, and to reflect on the social values being sought through struggle, which are not always clear in many laws and reports related to this issue (Berghs et al., 2019). Despite the consolidation of the right to a dignified life, society still has not achieved a high level of inclusion, not to mention the disadvantages that may or may not arise from disability (Riddle, 2020a), as well as from regulatory rulings that limit a positive connotation of group differences (which critical disability studies aim to eliminate), and prejudices that use dissimilarity to criticise

Article translated by Charles Edmond Arthur.

Project PID2019-105398RB-C21. Disability and Digital Skills in the Audio-visual Sector (COMPENSA), funded by the Ministry of Science and Innovation - State Research Agency/10.13039/501100011033. 
disability (Vehmas and Watson, 2014). Both the social model of disability, or in other words, the social injustice and stigma associated with disability that can be eliminated, and the human rights model (disability policy), are actually complementary, with the latter having greater importance in the legal and policy-oriented context, yet both models focus the main problem on social factors outside the individual (Lawson and Beckett, 2020).

The use of adaptive ICTs has highlighted skills development for the independence of young people with disabilities (Pacheco, Lips and Yoong, 2019), although it has taken a very long time to bridge the disability digital divide through accessibility as well as inclusive, innovative design (Pullin, 2011). Thus, people with disabilities have had to adapt to techno-social standards, and infrastructure has had to undergo a redesign in order to accommodate this situation (Yu et al., 2019), even though there is also digital exclusion that affects people based on the type and degree of disability, digital skills, and socio-economic circumstances (Dobransky and Hargittai, 2016). Specifically, the thirdlevel theory of the digital divide focuses less on digital access and usability and more on the social, economic, and personal consequences of digital access (Ragnedda, 2017). In fact, young people with disabilities actively interact with adaptive technology in the same way as their non-disabled peers in their inclusion at the university level (Pacheco, Yoong and Lips, 2020).

Social networks have also enabled people with physical disabilities to gain instrumental and informational support, with positive effects on building social reinforcement, lower tendency toward symptoms of depression (Lee and Cho, 2018), and greater social integration of people who are more isolated outside the online environment (Banjanin et al., 2015). Likewise, people with intellectual disabilities have had positive experiences on social networks in terms of friendships, social identity development, self-esteem and enjoyment (Caton and Chapman, 2016). Social support can be received structurally from the point of view of the extent and form of structural connections, or functionally, consisting of emotional, instrumental or practical help, informational support, and selfevaluation in relation to others (House, 1981; Sherbourne and Stewart, 1991).

Social networks also allow individuals to control how and when they disclose information about their disability based on their online relationships, or in other words, whether they choose to do so in a way that is open, safe, or limited (Furr, Carreiro and McArthur, 2015). However, it seems that the psychological benefits of using digital technology result primarily from the anonymity with which people with disabilities interact on the Internet and social networks (Tsatsou, 2020), although a person can build their identity in a positive way until they decide to disclose their disability (Bowker and Tuffin, 2002). The most recent studies conducted in medical centres have revealed that half of the patients surveyed who have intellectual and/or developmental disabilities do not use mobile devices $(44.6 \%)$, and that the majority $(86.8 \%)$ do not use social networks (Patrick et al., 2020).

Consequently, this research aims to answer the following questions: How are the fundamental rights of people with disabilities disseminated on social networks that represent them? What social discourse is transmitted during the International Day of Persons with Disabilities? Which posts on social networks achieve greater interaction 
depending on the informative, commemorative, or vindicatory messages they disseminate?

\section{Methodology}

The overall objective of this research is to analyse the content published on social networks on the International Day of Persons with Disabilities 2020 in order to identify the social discourse of specialised organisations.

The specific objectives are as follows:

- Identify public and private organisations specialising in disability that generated posts on their social networks on the International Day of Persons with Disabilities 2020.

- Determine which fundamental rights are explicitly addressed in their social discourse.

- Identify what type of content attains the highest level of interaction.

- Compare the reach that the organisations obtain through the social networks they use.

The quantitative content analysis was carried out using on-demand computational tools that use the API of the four main social networks: Facebook, Twitter, Instagram, and YouTube. All the posts were collected for the date analysed and ranked according to the highest number of interactions they received, while the data on the interactions attained was recorded from their date of publication until 11 January 2021. A qualitative analysis of these posts was also carried out using Atlas.ti v.8.4.4 software, which has helped to reduce the number of redundant concepts that are present in social discourse (Benavides-Delgado, 2005).

The International Day of Persons with Disabilities was chosen based on its status as a day on which commemorative and vindicatory discourses converge, so that specialised organisations communicate their priorities within their main areas of activity. The selection of the sample was based on the directory of public and private organisations that operate in Spain and specialise in people with disabilities. The directory has been developed within the framework of the COMPENSA R\&D\&i project (https://proyectocompensa.es/datos) and has involved the analysis of all the posts of the 18 organisations that have met the requirements of having operational social networks, or in other words, that have updated content, and that published messages on social networks on the International Day of Persons with Disabilities 2020. The directory includes the following organisations: Asociación Empresarial para la Discapacidad [Business association for disability] (AEDIS); Asociación de Atención a Personas con Discapacidad Intelectual [Association for the Care of People with Intellectual Disabilities] (APSA); Federación Española de Enfermedades Neuromusculares [Spanish Federation of Neuromuscular Diseases] (ASEM); Confederación Española de Asociaciones de Atención a las Personas con Parálisis Cerebral [Spanish Confederation of Associations for the Care of Persons with Cerebral Palsy] (ASPACE); Asociación Española de Familias de Personas con Sordoceguera [Spanish Association of Families of People with Deafblindness] (APASCIDE); Asociación Proyecto Autismo [Autism Project Association] (ASPAU); Autismo España [Autism Spain]; Comité Español de Representantes de Personas con 
Discapacidad [Spanish Committee of Representatives of People with Disabilities] (CERMI); Confederación Estatal de Personas Sordas [State Confederation of Deaf People] (CNSE); Confederación Española de Personas con Discapacidad Física y Orgánica [Spanish Confederation of People with Physical and Organic Disabilities] (COCEMFE); Down España [Down's Syndrome Spain]; Federación Española de Daño de Cerebral [Spanish Federation of Brain Injury] (FEDACE); Confederación Española de Familias de Personas Sordas [Spanish Confederation of Families of Deaf People] (FIAPAS); Fundación ONCE [ONCE Foundation]; Ilunion; Organización Nacional de Ciegos Españoles [Spanish National Organisation of the Blind] (ONCE); Plena Inclusión; and Servimedia.

\section{Results}

\section{Typologies, resources and scope of the posts}

The 18 disability organisations that made up the final sample posted a total of 122 messages on social media on the International Day of Persons with Disabilities (Figure 1 ), excluding those that referred to news unrelated to disability: 43 on Facebook, 50 on Twitter, 25 on Instagram, and 4 videos on YouTube.

Figure 1. Total number of posts per social network

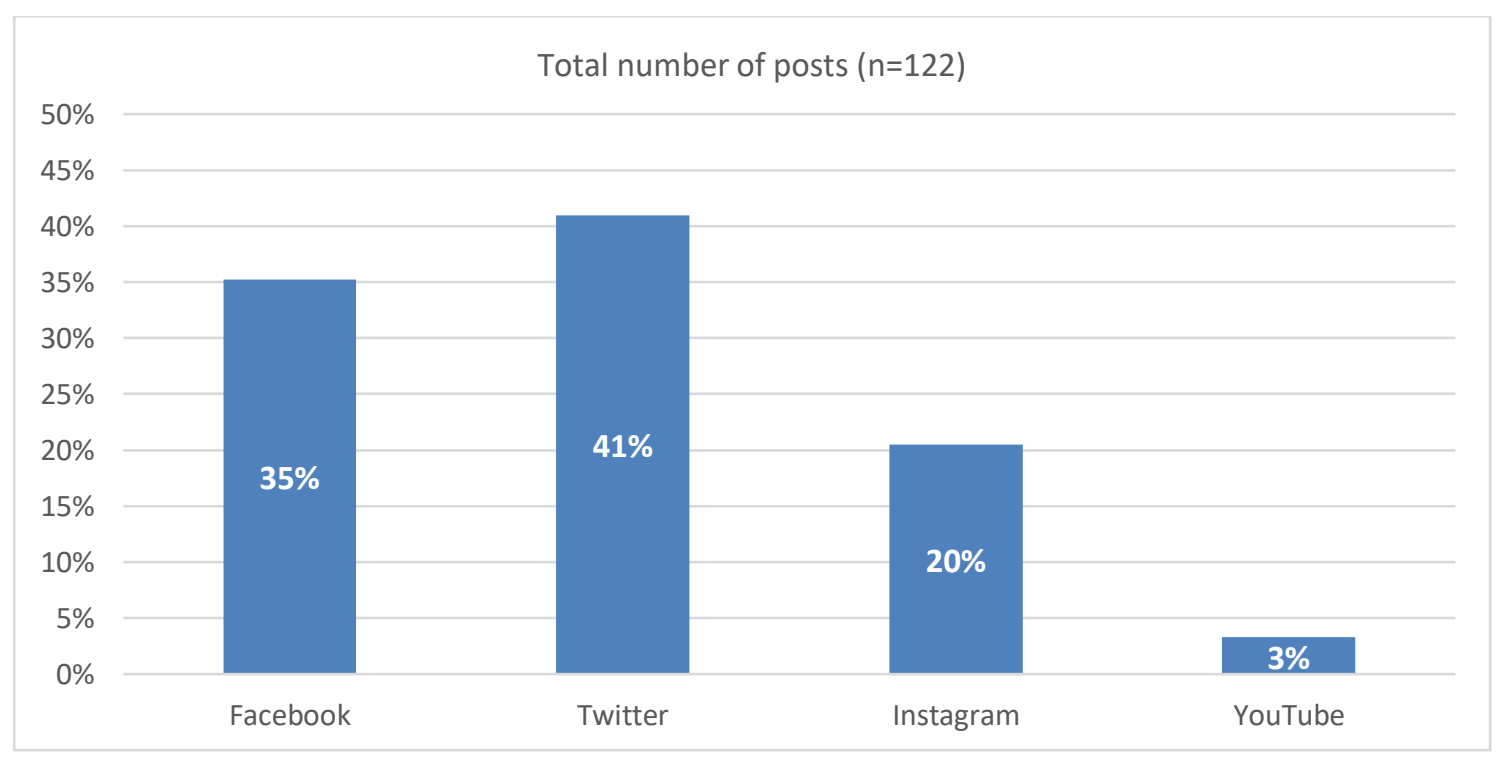

Source: Prepared by the authors

Organisations specialising in people with disabilities hardly make any reference to the specific purpose of their activity (Figure 2), beyond generalities with regard to providing care service or information about people with disabilities. Twitter is the site where the organisations make the most references to their objectives in their posts, accounting for $30 \%$ of the posts published, followed by YouTube $(25 \%)$, Instagram $(20 \%)$ and Facebook $(18.60 \%)$. In this way, the opportunity to spread information about the specific problems affecting the particular group in which they specialise is lost, although one can observe 
that there is a tendency for associations with less communicative resources to join larger and more representative organisations in order to show solidarity or support their initiatives.

Figure 2. References made regarding the mission of the organisations in their posts

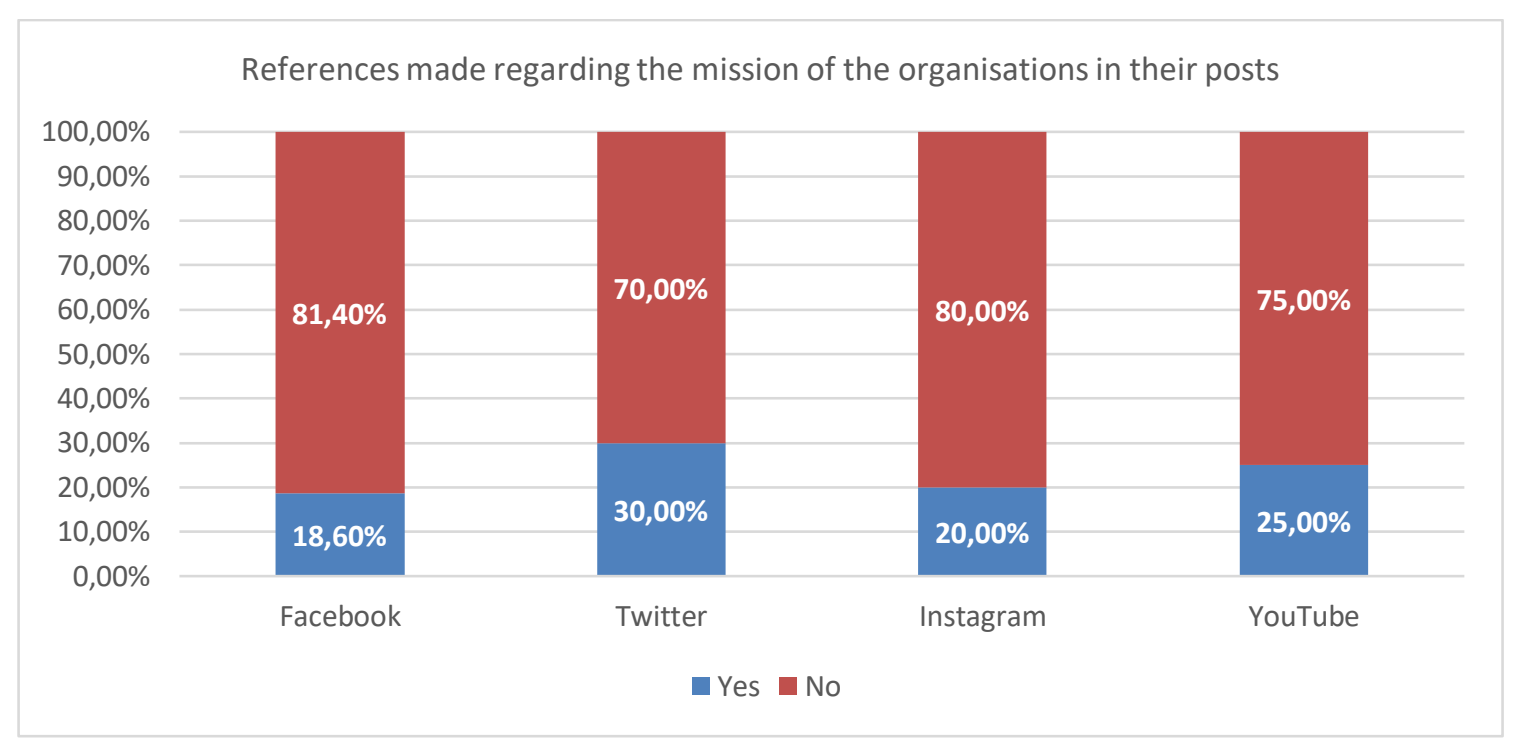

Source: Prepared by the authors

With regard to the audio-visual resources used by the organisations in their posts (Figure 3 ), they fail to take advantage of the possibilities offered by these resources to facilitate access for people with disabilities, despite the specialised nature of these organisations. Thus, the use of accessible video with subtitles is low, even with sign language dubbing in the case of ONCE, ONCE Foundation, and Ilunion, and is only present in $16 \%$ of the posts on Twitter, $12 \%$ on Instagram, $11.63 \%$ on Facebook, and $50 \%$ on YouTube, the latter figure being influenced by the fact that the two videos are published by the largest organisation in the sector, which is the ONCE Foundation.

The other half of the videos on YouTube (even though there are only two) are not subtitled, which could entail accessibility problems for users with certain types of disabilities. The presence of these videos is reduced to $4.65 \%$ on Facebook and $2 \%$ on Twitter, with no cases identified on Instagram. The use of the organisation's logo, or an anniversary, as the only image provided occurs on Facebook (4.65\% of the posts) and Twitter (4\%), with text appearing as the only resource mainly on Twitter ( $14 \%$ of posts) and to a lesser extent on Facebook (4.65\%). In any case, images are the visual resource most heavily used on the three main social networks, with a higher incidence on Instagram (88\%) than on Facebook (72.09\%) and Twitter (64\%), despite the fact that no use is made of either tags or alternative text with descriptions that facilitate accessibility for all people with disabilities.

In the discourse on social networks of organisations specialising in people with disabilities, which is developed in the following section, there are frequent references to 
the need for a digital transition in which technological innovation would foster inclusion and accessibility to information and communication. However, the use of technology is minimal, both in the resources used and in the discourse that emanates from the posts on social networks of these associations and foundations: QR codes, traditional audiovisual content (TV commercials, animated videos), Zoom video conferences, infographics with data, a live broadcast on Instagram on one occasion, an award-winning accessible app, and the setting up of a laboratory by people with intellectual disabilities.

Figure 3. Audio-visual resources used in the posts

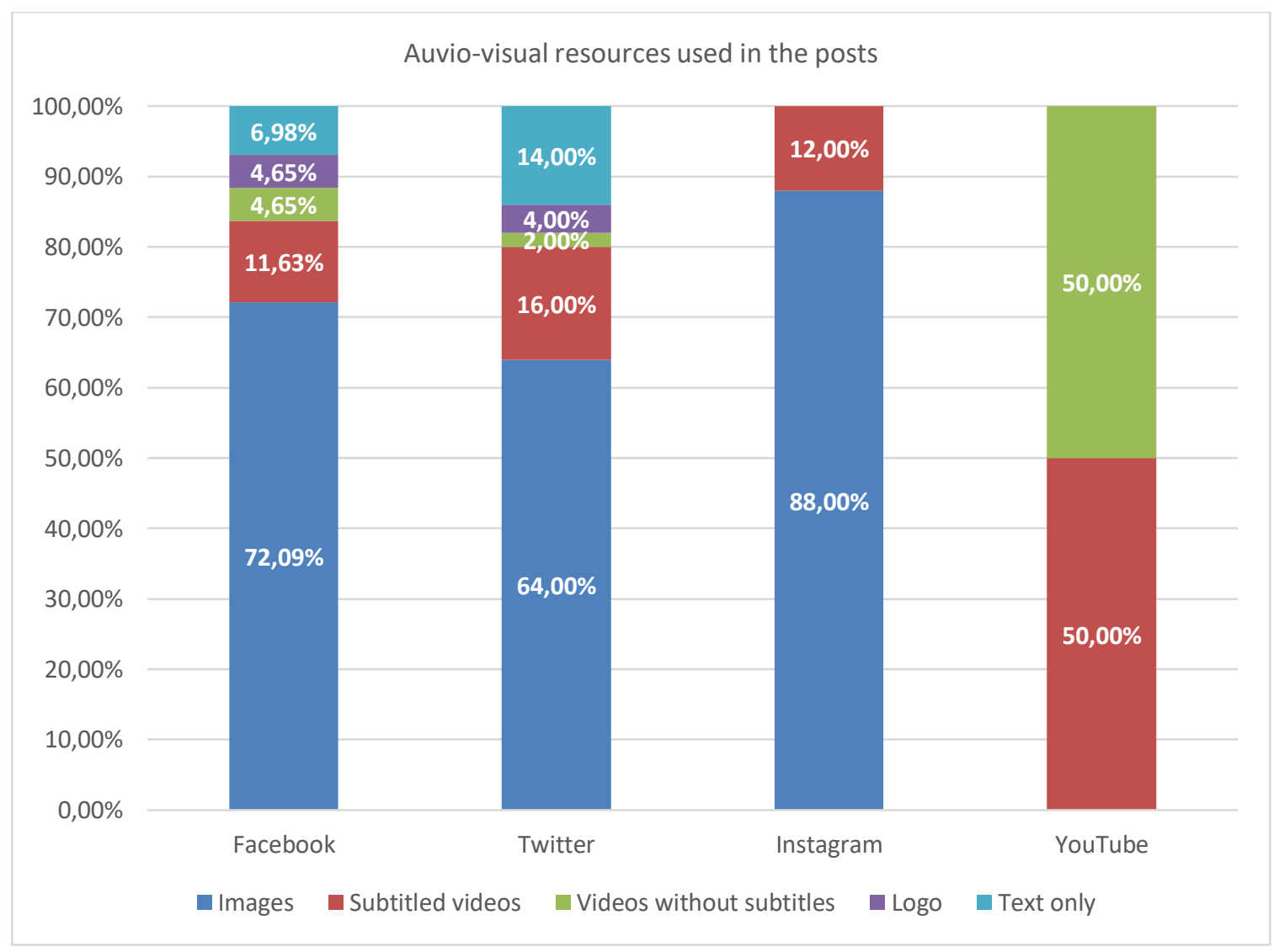

Source: Prepared by the authors

In relation to audio-visual resources, an analysis as to whether the information published is expanded through links has also been conducted (Figure 4). This question is relevant given the lack of accessible technological and audio-visual resources detected. However, in three of the four social networks analysed, the percentages of the posts that have a link are between $50 \%$ (YouTube) and 58\% (Twitter), with an exceptionally high presence only on Instagram, where $84 \%$ of the posts include a link that usually leads to the text of the websites where associations and foundations have greater chances of providing accessible formats for the information produced. 


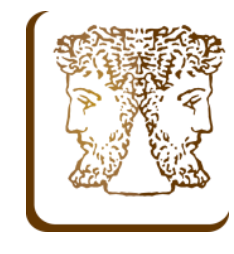

Figure 4. Links used in the posts

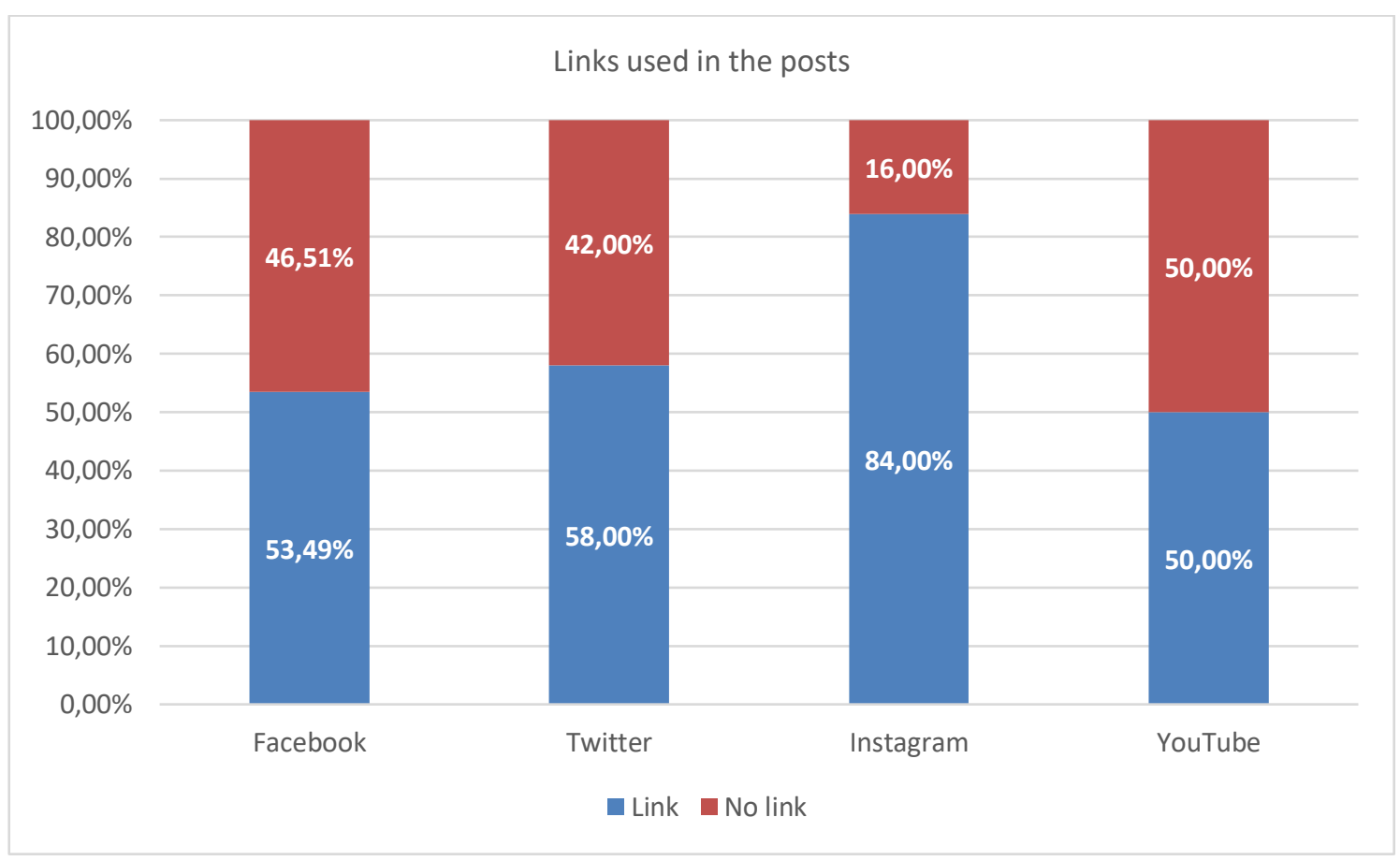

Source: Prepared by the authors

Disability organisations are also missing the opportunity to extend the reach of their posts by not using specific hashtags (\#) (Figure 5) for the International Day of Persons with Disabilities, for the organisation promoting the publication, or both, which would be the most effective. In fact, the majority of the posts on all the social networks do not use any of these hashtags, especially on YouTube (absence in $75 \%$ of all posts) and Instagram (72\%), in contrast to Facebook (55.81\%) and Twitter (44\%).

The hashtag for International Day is the most heavily used on all the social networks, although there is clearly no consensus on the use of a representative hashtag, as several names have appeared, sometimes according to the date, and at other times according to the name of the entire commemorative day, or a short version of it, which makes it even more difficult to achieve the desired reach of the posts. On Facebook, the hashtag of International Day and the of the posting organisations is present in $18.60 \%$ of the posts, whereas $6.98 \%$ use both hashtags. Twitter, however, is the social network where both the hashtag of International Day (36\%) and the of the organisation itself ( $8 \%)$ are most used. On Instagram, the hashtag of International Day appears in 16\% of the posts, yet never appears in combination with the of the organisation, and on YouTube, the hashtag of International Day appears in $25 \%$ of the posts, yet it never appears together with the of the organisation. On both Twitter and Instagram, the hashtag representing the organisation is present in $12 \%$ of the posts, while it is not used in any of the posts analysed on YouTube. 
Figure 5. Hashtags used in the posts

Hashtags (\#) used in the posts

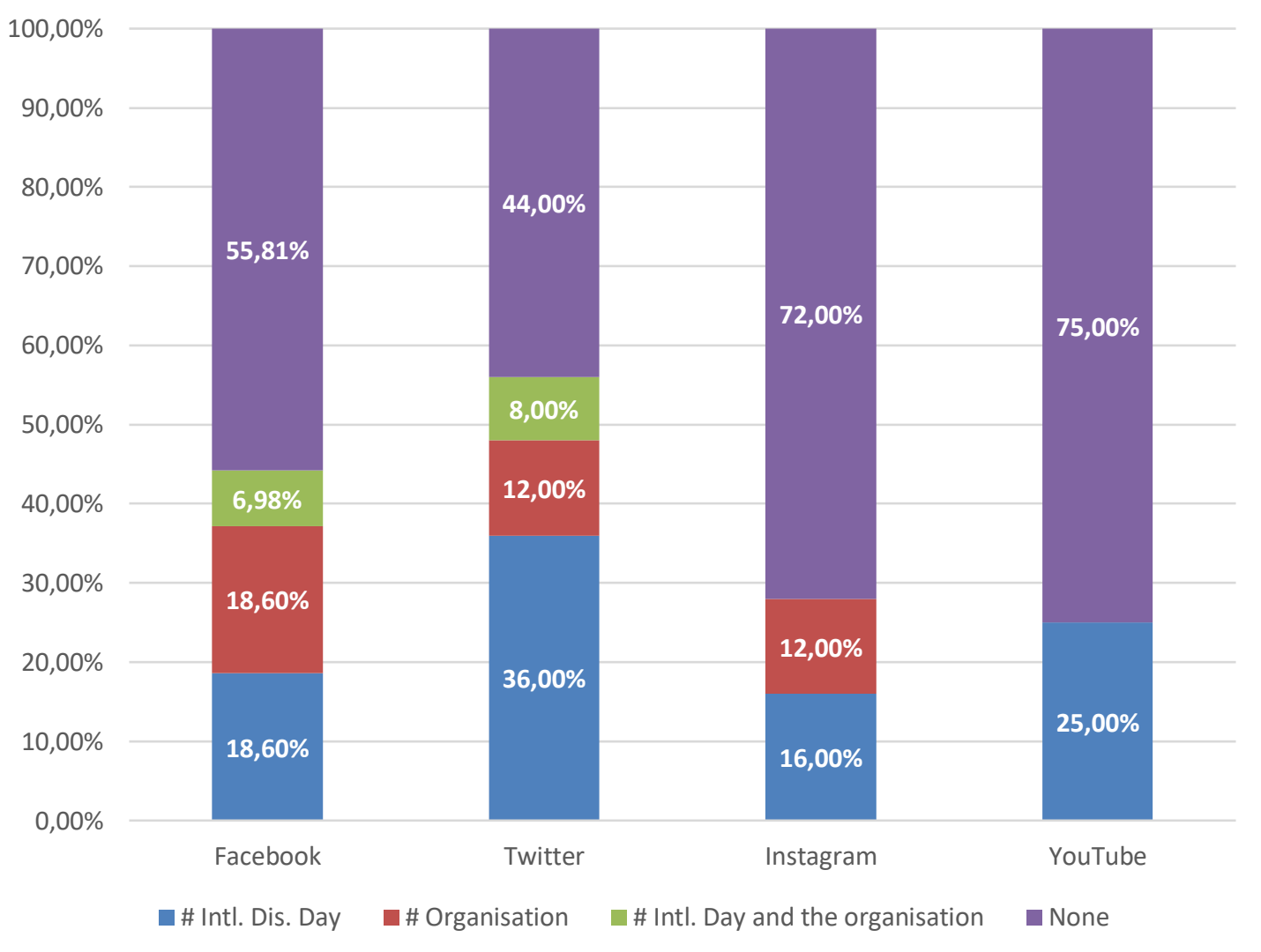

Source: Prepared by the authors

Facebook is the social network on which a higher number of organisations are present (Figure 6), and is similar for Twitter (18 vs. 14, respectively), precisely because they are the two most widely-used social networks among the older public, and consequently easier to manage for organisations that often have a shortage of specialised staff. The most active organisations on Facebook are ASPAU (11.63\% of posts), CERMI (11.63\%), COCEMFE $(11.63 \%)$, Servimedia $(9.30 \%)$ and FIAPAS $(6.8 \%)$. The most active on Twitter are CERMI (16\%), COCEMFE (10\%) and Plena Inclusión (10\%), while on Instagram and YouTube there is a greater concentration of larger organisations with more resources. 
Thematic dossier - International Relations and Social Networks (July 2021), pp. 93-111 Fundamental rights of people with disabilities reflected in the social discourse of the main disability organisations in Spain

Figure 6. Total posts on each social network by organisation

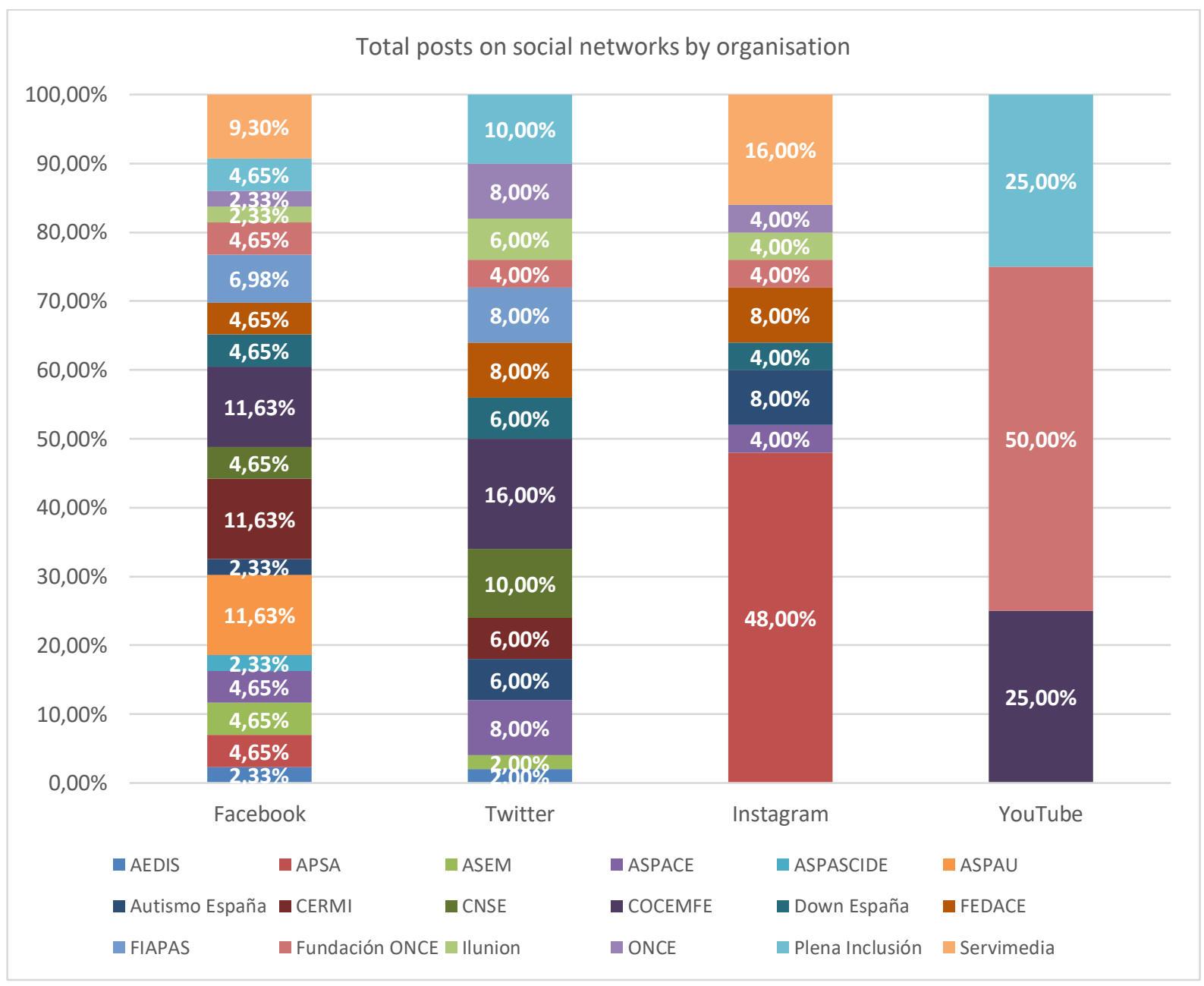

Source: Prepared by the authors

However, the reach and interaction achieved by these organisations is uneven (Table 1 ). Although ASPAU, CERMI, COCEMFE and Servimedia, respectively, have been the most active in posting on Facebook, COCEMFE has the lowest percentage of interactions $(0.03 \%)$ (Table 1$)$, followed by APASCIDE $(0.11 \%)$, ASPAU $(0.14 \%)$, CERMI $(0.26 \%)$, Down España $(0.39 \%)$, and COCEMFE (0.49\%). Consequently, despite having a high number of followers (ASPAU with 3.5 million and COCEMFE with 19,153), the number of reactions, comments or shares they achieve in relation to the number of people who see their posts is very low. The entities that get the most interaction are APSA $(1.66 \%)$, Ilunion $(1.56 \%)$ and CNSE $(1.21 \%)$, despite being among those that posted the least. 


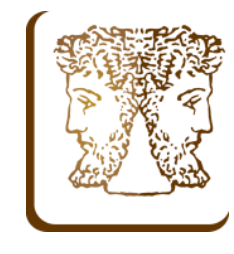

Table 1. Interaction achieved on Facebook

\begin{tabular}{|c|c|c|c|c|c|}
\hline Organisation & Followers & $\begin{array}{l}\text { No. of } \\
\text { posts }\end{array}$ & $\begin{array}{c}\text { Reactions, } \\
\text { comments, and } \\
\text { shares }\end{array}$ & $\begin{array}{c}\text { Commitment } \\
(\%)\end{array}$ & $\begin{array}{c}\text { Interactions } \\
(\%)\end{array}$ \\
\hline AEDIS & 575 & 1 & 3 & $0.52 \%$ & $0.52 \%$ \\
\hline APASCIDE & 922 & 1 & 1 & $0.11 \%$ & $0.11 \%$ \\
\hline$A P S A$ & 7,787 & 2 & 259 & $3.33 \%$ & $1.66 \%$ \\
\hline ASEM & 5,746 & 2 & 90 & $1.57 \%$ & $0.78 \%$ \\
\hline$A S P A C E$ & 15,365 & 2 & 218 & $1.42 \%$ & $0.71 \%$ \\
\hline$A S P A U$ & 3.5 million & 5 & 24,220 & $0.70 \%$ & $0.14 \%$ \\
\hline Autismo España & 37,620 & 1 & 203 & $0.54 \%$ & $0.54 \%$ \\
\hline CERMI & 7,774 & 5 & 102 & $1.31 \%$ & $0.26 \%$ \\
\hline CNSE & 24,667 & 2 & 595 & $2.41 \%$ & $1.21 \%$ \\
\hline COCEMFE & 19,153 & 5 & 467 & $2.44 \%$ & $0.49 \%$ \\
\hline Down España & 52,457 & 2 & 404 & $0.77 \%$ & $0.39 \%$ \\
\hline FEDACE & 8,893 & 2 & 97 & $1.09 \%$ & $0.55 \%$ \\
\hline FIAPAS & 6,314 & 3 & 100 & $1.58 \%$ & $0.53 \%$ \\
\hline Fundación ONCE & 32,479 & 2 & 301 & $0.93 \%$ & $0.46 \%$ \\
\hline Ilunion & 16,436 & 1 & 257 & $1.56 \%$ & $1.56 \%$ \\
\hline ONCE & 44,080 & 1 & 259 & $0.59 \%$ & $0.59 \%$ \\
\hline Plena Inclusión & 57,770 & 2 & 568 & $0.98 \%$ & $0.49 \%$ \\
\hline Servimedia & 4,696 & 8 & 11 & $0.23 \%$ & $0.03 \%$ \\
\hline
\end{tabular}

Source: Prepared by the authors

The interaction data are nearly irrelevant in the case of Twitter, where FIAPAS reaches the highest level of interaction at $0.64 \%$, with only four other entities obtaining an interaction of $0.10 \%$ : COCEMFE $(0.25 \%)$, ASEM $(0.19 \%), \operatorname{CNSE}(0.17 \%)$ and AEDIS $(0.14 \%)$. Instagram is the site where the percentage of interactions is highest, with standouts including Ilunion (5.63\%), ONCE (3.74\%), APSA (2.84\%) and Down España $(2.34 \%)$. On YouTube, the fact that only 3 organisations published 4 videos limits the analysis, but the number of views among the total number of subscribers to the Fundación ONCE channel is $8.75 \%$, the Plena Inclusión channel attained $3.70 \%$, and the COCEMFE channel had $1.92 \%$.

\section{Topics of the discourse posted by the specialised organisations}

When structuring the discourse by topic in the posts on social networks on the International Day of Persons with Disabilities (Figure 7), the pattern on Facebook and Twitter is very similar, with a majority of posts combining commemoration and vindication (32.56\% on Facebook and $30 \%$ on Twitter). In addition, one must add the use of the topic of commemoration of International Day $(6.98 \%$ on Facebook and $10 \%$ on Twitter), as well as the demand for specific solutions or rights for persons with disabilities ( $6.98 \%$ on Facebook and $14 \%$ on Twitter). There is also a more positive topic combination that joins commemoration and acknowledgement $(6.98 \%$ on Facebook and 
$4 \%$ on Twitter), either for users, workers, volunteers, or society itself for its support and effort. Also noteworthy is the publication of news related to people with disabilities, the holding of conferences, meetings, round tables, etc. ( $18.60 \%$ on Facebook and $24 \%$ on Twitter), as well as the announcement of awards received by associations and foundations or granted by them (9.30\% on Facebook and $6 \%$ on Twitter).

On Instagram, however, $48 \%$ of the posts are oriented toward fundraising, even though there is some distortion due to the fact that APSA accounts for $48 \%$ of the total number of posts on Instagram, all of which are related to the sale of a solidarity calendar. This social network differs from the others in showing a higher number of commemoration and acknowledgement posts (16\%), with a substantial reduction in commemoration and vindication (12\%) and most of all in vindication (4\%), thus revealing the opportunities for topic specialisation that these organisations can adopt depending on the profile and characteristics of each social network.

In the case of YouTube, the four posts are equally distributed (25\% each) among the following topics: commemoration; commemoration and vindication; news/conferences/meetings; and awards.

Figure 7. Post topics by social network

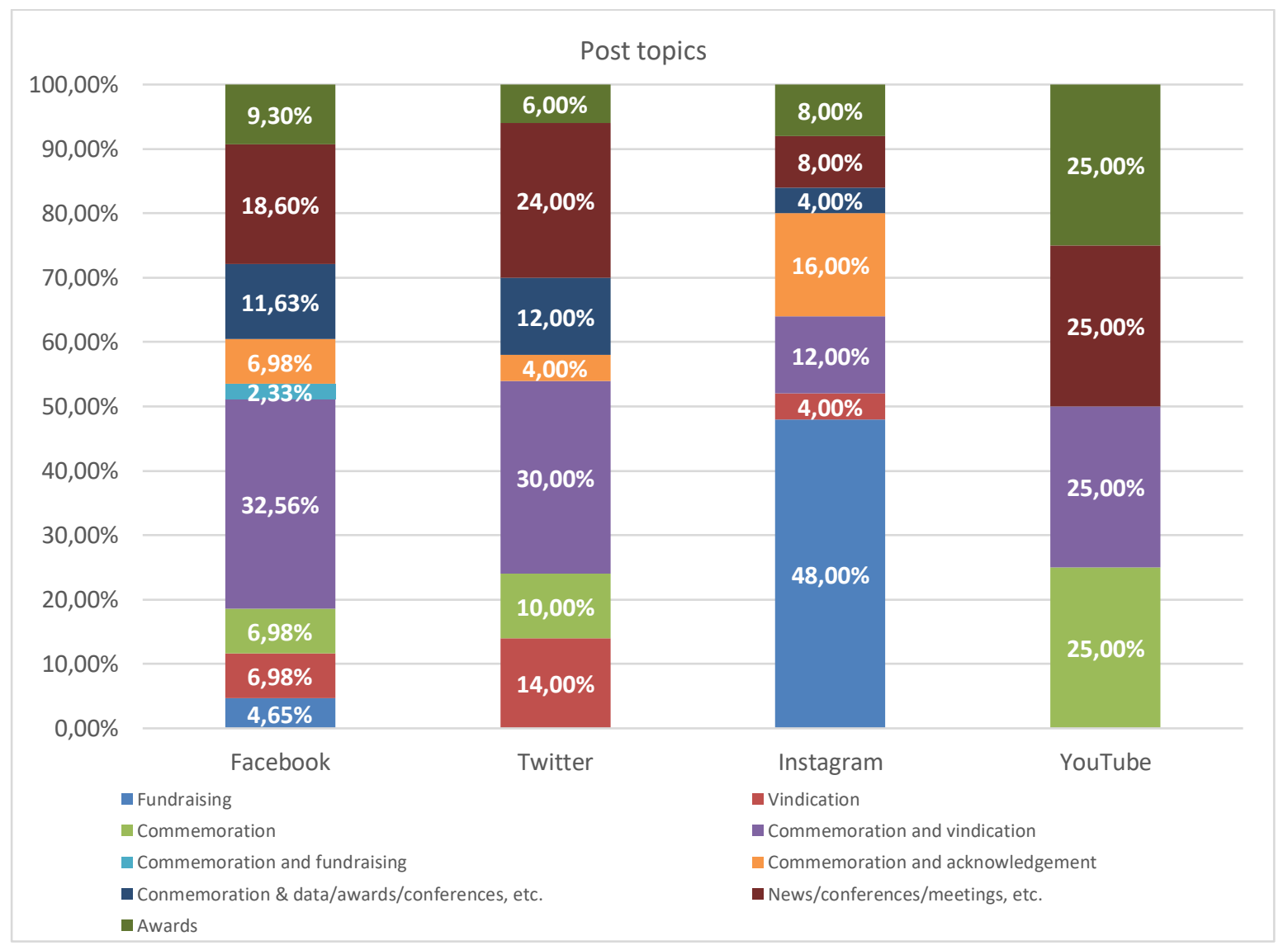

Source: Prepared by the authors 


\section{The rights of people with disabilities in social discourse}

The rights of people with disabilities that specifically appear in the analysis of the discourse presented in the social network posts of the organisations specialising in this issue (Figure 8 ) are similar on all social networks, despite the greater intensity with which they appear depending on the peculiarities of each social network. The results of this section are not presented in percentages, because sometimes more than one right appears in each publication. Consequently, with regard to the rights included in the general principles of the International Convention on the Rights of Persons with Disabilities, held in 2006, reference is made to the number of times each of these rights is mentioned, which are structured as follows:

a) Respect for inherent dignity, individual autonomy including the freedom to make one's own choices, and independence of persons;

b) Non-discrimination;

c) Full and effective participation and inclusion in society;

d) Respect for differences, and acceptance of persons with disabilities as part of human diversity and humanity;

e) Equalilty of opportunity;

f) Accessibility;

g) Equality between men and women;

h) Respect for the evolving capacities of children with disabilities and respect for the right of children with disabilities to preserve their identities. (United Nations, 2006: 5)

Firstly, the right to participation and inclusion of people with disabilities in society stands out, with the highest number of mentions on Facebook, Twitter, and Instagram, although this right does not appear on YouTube. Of particular note in this section is the declaration by CERMI, which has been endorsed and supported by many other organisations in their posts and advocates the participation of people with disabilities in the social and economic reconstruction in the post-pandemic scenario, so as not to increase the gap that continues to exist with regard to the full inclusion of people with disabilities. Such participation and inclusion is also reflected in specific messages oriented toward commemoration of International Day, such as the slogan, "A day for all". The use of inclusive language (and specifically inclusive behaviour) is another expression of this right in the posts, as well as the necessary e-inclusion that must be adopted more decisively in education. These rights are even presented in a way that is interrelated when it is claimed that inclusive language should effectively promote the full participation of people with disabilities in today's society, and that doing so requires greater technological innovation to offer support for different types of disabilities, without ever forgetting the universal nature that inclusion must entail.

Accessibility is the second most frequently mentioned right in the discourse that has emerged from the posts on the four social networks analysed, especially on Twitter, Facebook and YouTube. Accessibility is presented by the organisations as a broad concept 
in which the removal of barriers stands out, sometimes referring to a physical issue, but on most occasions referring to the term in a more general way. The current nature of the health crisis can also be seen in the elimination of the barrier of masks for communication with people with hearing disabilities, or other types of barriers that have emerged in people with cognitive disabilities due to the restrictions imposed, which are issues related to other rights as well.

Individual autonomy also has a strong presence on Facebook, Twitter and Instagram, from the perspective of both health and well-being, showing a clear reaffirmation of the dignity and dignified living conditions of people with disabilities and their families, and demanding quality care for them with real support that makes the former possible. With regard to individual autonomy, during the commemoration of International Day many organisations celebrated the news of the Spanish Parliament's decision to eliminate forced sterilisation of people with disabilities who were declared to be incapacitated by court order, which was a decision that these entities had been demanding for decades.

Substantially fewer mentions were made of both the right to non-discrimination and the right to equal opportunity. Regarding the right to non-discrimination for people with disabilities, the organisations focus on using constructive dialogue to fight against hate speech on social networks. On the other hand, equal opportunity is focused on employment.

With only three mentions, respect for differences and the acceptance of people with disabilities as part of human diversity and the human condition is related to the need for support and the preservation of dignity. With two mentions, the right to gender equality is presented from the perspective of gender-based violence with an emphasis on women with cerebral palsy. The only mention made of developing aptitudes and identity refers to the fact that a disability is not something that is suffered nor possessed.

Figure 8. Explicitly mentioned rights of people with disabilities by social network Explicitly-mentioned rights of people with disabilities in the posts $(n=122)$

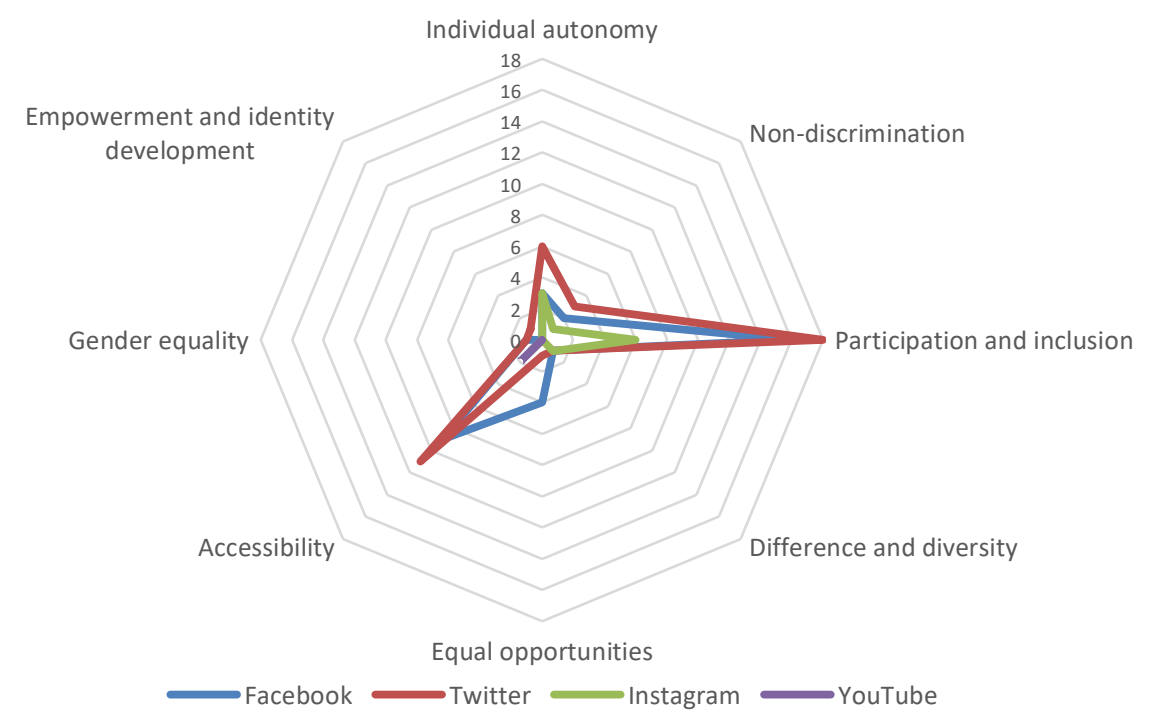

Source: Prepared by the authors 
The ten posts with the highest number of "Likes" (Table 2) are on Facebook (with the remarkable fact that ASPAU has 3.5 million followers), and Instagram. This order has been chosen considering the low level of interaction analysed. These ten posts stand out for their variety, and they are represented by six different organisations, with a majority presence related to the commemoration of International Day of Persons with Disabilities, the demand for participation and inclusion, accessibility, and autonomy.

Table 2. Posts with the most Likes among all the social networks

\begin{tabular}{|c|c|c|c|}
\hline $\begin{array}{l}\text { Social } \\
\text { Network }\end{array}$ & Organisation & Post & Likes \\
\hline Facebook & $A S P A U$ & $\begin{array}{l}\text { 3rd DECEMBER, INTERNATIONAL DAY OF DISABILITY } 0<3 \text {. } \\
\text { Disability Day, because there is still a lot to do. } \\
\text { quiéretemucho.com }\end{array}$ & 4,293 \\
\hline Facebook & $A S P A U$ & $\begin{array}{l}\text { The only truly dangerous disability is not having a heart. 3rd } \\
\text { December. International Day of Persons with Disabilities }\end{array}$ & 3,396 \\
\hline Facebook & $A S P A U$ & $\begin{array}{l}\text { To include means not only to let someone in, but to } \\
\text { WELCOME them. ASPAU Autism Project Association }\end{array}$ & 2,443 \\
\hline Facebook & $A S P A U$ & $\begin{array}{l}\text { 3rd DECEMBER, INTERNATIONAL DAY OF PERSONS WITH } \\
\text { DISABILITIES. That is what normality is all about. We all } \\
\text { want to be on the inside, and not excluded. Even if it means } \\
\text { hurting ourselves and causing harm. -Nacho Calderón } \\
\text { Almendros- }\end{array}$ & 871 \\
\hline Instagram & ONCE & $\begin{array}{l}\text { ONCE and Telefónica, united by innovation for } \\
\text { inclusion. O Today, on the \#DíaDeLaDiscapacidad (Day of } \\
\text { Disability), Paco, who is one of the sales vendors in our } \\
\text { network of more than } 19,000 \text { guardians of \#hope, tells us } \\
\text { how the technology of his POS terminal helps him and } \\
\text { others every day in their work. Full story on \#PeopleFirst } \\
\text { @ttps://blogthinkbig.com/peoplefirst/terminal-accesible- } \\
\text { once-telefonica \#tecnologíaaccesible \#accesibilidad } \\
\text { \#innovación \#discapacidad }\end{array}$ & 406 \\
\hline Instagram & $\begin{array}{l}\text { Down } \\
\text { España }\end{array}$ & $\begin{array}{l}\text { From DOWN ESPAN } A \text { (Down's Syndrome Spain), we want to } \\
\text { take advantage of the opportunity on this International Day } \\
\text { of Persons with Disabilities to advocate, together with } \\
\text { @cermi_estatal, the universal acceptance of inclusion by } \\
\text { providing support that is genuine, adequate, and } \\
\text { individualised in all areas of life for people with disabilities, } \\
\text { as well as the creation of an authentic social and health care } \\
\text { space to act as a welfare provider and support network to } \\
\text { guarantee assistance for decent living conditions for people } \\
\text { with complex needs. }\end{array}$ & 359 \\
\hline Instagram & $\begin{array}{l}\text { Autismo } \\
\text { España }\end{array}$ & $\begin{array}{l}\text { People with \# discapacidad (disabilities) are among the } \\
\text { hardest hit by the \#COVID19 pandemic. On } \\
\text { \#DiaInternacionalDiscapacidad (International Disability Day) } \\
\text { we join the manifesto of @cermi_estatal and demand to be } \\
\text { part of the economic and social reconstruction. +Info with } \\
\text { \#pictos \#TEA \#autism in } \_ \text {Current events- } \\
\text { www.autismo.org.es }\end{array}$ & 299 \\
\hline Instagram & Ilunion & $\begin{array}{l}\text { !! Today we commemorate the International Day of Persons } \\
\text { with Disabilities (\#Discapacidad) with the slogan 'A Day for } \\
\text { All'. A day for everyone to show their appreciation, in this } \\
\text { highly complicated year, for all the efforts and commitment } \\
\text { of more than } 15,000 \text { people with disabilities who are part of } \\
\text { \#ILUNION }\end{array}$ & 262 \\
\hline
\end{tabular}




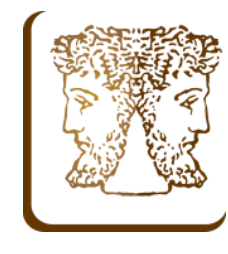

\begin{tabular}{|l|c|l|c|}
\hline Instagram & $\begin{array}{c}\text { Autismo } \\
\text { España }\end{array}$ & $\begin{array}{l}\text { E. Go Parliament permanently outlaws forced or non- } \\
\text { consensual sterilisation of people judged to be incapacitated } \\
\text { by court decree. We celebrate this historic milestone that will } \\
\text { especially benefit girls and women with \#disabilities \#TEA } \\
\text { \#autism We leave you +Info in Current events - } \\
\text { www.autismo.org.es }\end{array}$ & 240 \\
\hline Facebook & CNSE & $\begin{array}{l}\text { The CNSE (State Confederation of Deaf People) and its } \\
\text { associated network publicly announce this Declaration for } \\
\text { the accessibility of deaf people. \# SomosRedCNSE }\end{array}$ & 233 \\
\hline
\end{tabular}

Source: Prepared by the authors

\section{Discussion and conclusions}

Although the activity of the 18 disability organisations analysed was moderate on their social networks on International Day of Persons with Disabilities, with an average of 6.78 posts each on the four social networks, most of it was concentrated on Twitter $(41 \%$ of the total number of posts) and Facebook (35\%). These results seem consistent with the increased effort in social network management that requires visually appealing photography, in the case of Instagram, and quality video recording and editing, in the case of YouTube. Previous research on digital communication of non-profit organisations has already highlighted the minimal professional structure they have in this area, and the result is heavier use of Facebook and Twitter as the two networks are most familiar to older people, who are usually the ones in charge of multiple tasks within these organisations, even regarding charity work (de-Cos-Carrera and Mañas-Viniegra, 2018).

Only three organisations have more than 50,000 followers on Facebook, and only three have more than $1 \%$ of the interactions achieved by the total number of their posts on International Day, which clearly shows the effectiveness of posting less but with higher quality content that is more interesting for the audience. Previous studies carried out with this same methodology in other areas such as the digital press, sponsoring brands and museums have revealed the difficulty in achieving numbers of interactions higher than $1 \%$ on Facebook and Twitter, yet the numbers are higher on Instagram. (MañasViniegra \& López-Cepeda, 2018; Mañas-Viniegra, Sierra-Sánchez and López-Cepeda, 2019; López-Cepeda and Mañas-Viniegra, 2020).

This research has revealed areas of potential improvement for increasing this low percentage of interaction, such as the following: publishing specific messages related to the disability sector in which the organisation specialises; using topic-related hashtags about an organisation's activity that specifically identify the organisation (such hashtags are currently non-existent with highly dispersed terms); using audio-visual resources to address accessibility, either with images or video, along with subtitles, which are often not included; and finally, greater use should be made of audio-visual technology. This shortcoming in terms of accessibility can partially be overcome by expanding the information published on a website that is outside the social network, yet more accessible, through the use of links. This approach is particularly used on Instagram, with a presence in $84 \%$ of the posts. Similarly, the posts of organisations with fewer resources are diluted by relying on material generated and published by other organisations, and consequently they hardly generate any content of their own. 
Commemoration and vindication took advantage of the social network discourse on the International Day of Persons with Disabilities, prioritising everything related to the human and fundamental rights of this group, with emphasis on the participation and inclusion of people with disabilities in society, accessibility, individual autonomy, and well-being. One can observe the way in which Twitter's own identity as a social network, which is more inclined toward protest and exalted discourse, also influences the more vindicatoryoriented activity of these organisations, but always with an institutional tone. On Instagram, the activity has focused on fundraising through the sale of solidarity calendars by one of the organisations, although this approach has also been used by the rest of the organisations to show their appreciation for the volunteers, users, and families for their support.

The limitations of this study stem from the scarcity of organisations specialising in people with disabilities that are also active on social networks, as well as the limitations in terms of scope and percentage of the interaction of their posts. Another limitation is the lack of data that would allow for a comparative study to be carried out, either with other years or with the activity on social networks during the rest of the year. Similarly, it would be useful to determine whether or not the Spanish case is typical of the situation in other European countries. On the other hand, it seems that the anonymity on both the Internet and social networks that provides psychological benefits to people with disabilities (Tsatsou, 2020) is drastically declining due to the influence on personal identity exerted by visual social networks with preferences for beauty and fashion (Mañas-Viniegra, Núñez-Gómez and Tur-Viñes, 2020), an issue that has already emerged as a future line of specific research on Instagram through the use of neurocommunication techniques. There is also a need for a cross-cultural study that would help to compare differences, depending on whether society is more inclusive or more individualistic (Alsaleh et al., 2019), and would also aid in understanding the use of digital skills by people with disabilities in promoting accessibility, and their own employability as well.

\section{References}

Alsaleh,D. A., Elliott, M. T., Fu, F. Q., \& Thakur, R. (2019). Cross-cultural differences in the adoption of social media. Journal of Research in Interactive Marketing, 13(1), 119140. https://doi.org/10.1108/JRIM-10-2017-0092

Banjanin, N., Banjanin, N., Dimitrijevic, I., \& Pantic, I. (2015). Relationship between internet use and depression: Focus on physiological mood oscillations, social networking and online addictive behavior. Computers in Human Behavior, 43, 308312. https://doi.org/10.1016/j.chb.2014.11.013

Benavides-Delgado, J. (2005). Nuevas propuestas para el análisis del lenguaje en los medios [New models for language analysis]. Questiones publicitarias, 1(10), 13-33. https://doi.org/10.5565/rev/qp.154

Berghs, M. ,Atkin, K., Hatton, C., \& Thomas, C . (2019). Do Disabled People Need a Stronger Social Model: A Social Model of Human Rights? Disability \& Society, 34(78), 1034-1039. https://doi.org/10.1080/09687599.2019.1619239 
Bowker, N., \& Tuffin, K. (2002). Disability Discourses for Online Identities. Disability \& Society, 17(3), 327-344. https://doi.org/10.1080/09687590220139883

Caton, S., \& Chapman, M. (2016). The use of social media and people with intellectual disability: A systematic review and thematic analysis. Journal of Intellectual \& Developmental Disability, 41(2), https://doi.org/10.3109/13668250.2016.1153052

De-Cos-Carrera, L., \& Mañas-Viniegra, L. (2018). La comunicación digital de las ONG españolas de apoyo al Sáhara [Digital communication of Spanish NGOs in support of Western Sahara]. Doxa Comunicación, 26, 13-34. https://doi.org/10.31921/doxacom.n26a1

Dobransky, K., \& Hargittai, E. (2016). Unrealized potential: Exploring the digital disability divide. Poetics, 58(3), 18-28. https://doi.org/10.1016/j.poetic.2016.08.003

Furr, J. B., Carreiro, A., \& McArthur, J. A. (2015). Strategic approaches to disability disclosure on social media. Disability \& Society, 31(10), 1353-1368. https://doi.org/10.1080/09687599.2016.1256272

House, J. S. (1981). Work stress and social support. Addison-Wesley.

Lawson, A., \& Beckett, A. E. (2020). The social and human rights models of disability: towards a complementarity thesis. The International Journal of Human Rights, 25(2), 348-379. https://doi.org/10.1080/13642987.2020.1783533

Lee, H. E., \& Choo, J. (2018). Social Media Use and Well-Being in People with Physical Disabilities: Influence of SNS and Online Community Uses on Social Support, Depression, and Psychological Disposition. Health Communication, 34(9), 1043-1052. https://doi.org/10.1080/10410236.2018.1455138

López-Cepeda, I., \& Mañas-Viniegra, L. (2020). La identidad corporativa de los museos españoles a través de sus interacciones de marca en redes sociales. In T. Bueno-Doral, I. González-Hernando, \& R. Navajas-Seco (Coords.), Cultura y tecnologías digitales socialmente responsables e innovadoras (pp. 57-67). Trea.

Mañas-Viniegra, L., \& López-Cepeda, I. (2018). Influencia de los resultados deportivos sobre las interacciones de marca generadas en medios sociales por los patrocinadores de la Selección Española durante el Mundial de Rusia 2018. In J. M. Albalad-Aiguabella, L. Busto-Salinas, \& V. Muñiz-Zúñiga (Coords.), Nuevos lenguajes de lo audiovisual (pp. 241-253). GEDISA.

Mañas-Viniegra, L., Núñez-Gómez, P., \& Tur-Viñes, V. (2020). Neuromarketing as a strategic tool for predicting how Instagramers have an influence on the personal identity of adolescents and young people in Spain. Heliyon, 6(3), e03578. https://doi.org/10.1016/j.heliyon.2020.e03578

Mañas-Viniegra, L., Sierra-Sánchez, J., \& López-Cepeda, I. (2019). Consumo e interacciones de las noticias publicadas en redes sociales por los diarios españoles y europeos [Consumption and Engagement of News Published on Social Networks by Spanish and European Newspapers]. Trípodos, 45, 135-156. https://doi.org/10.51698/tripodos.2019.45p135-156 
Naciones Unidas (2006). Convention on the Rights of Persons with Disabilities. https://bit.ly/3rSqnj8

Oliver, M. (2004). If I had a hammer: The social model in action. In J. Swain, S. French, C. Barnes, \& C. Tomas (Eds.), Disabling barriers. Enabling environments (2nd. Edition) (pp. 7-12). Sage.

Pacheco, E., Lips, M., \& Yoong, P. (2019). ICT-enabled self-determination, disability and young people. Information, Communication \& Society, 22(8), 1112-1127. https://doi.org/10.1080/1369118X.2017.1406972

Pacheco, E., Yoong, P., \& Lips, M. (2020). Transition issues in higher education and digital technologies: the experiences of students with disabilities in New Zealand. Disability \& Society, 36(2), 179-201. https://doi.org/10.1080/09687599.2020.1735305

Patrick, P. A., Obermeyer, I., Xenakis, J., Crocitto, D., \& O'Hara, D. M. (2020). Technology and social media use by adult patients with intellectual and/or developmental disabilities. Disability and Health Journal, 13(1), 100840. https://doi.org/10.1016/j.dhjo.2019.100840

Pullin, G. (2011). Design meets disability. MIT Press.

Ragnedda, M. (2017). The Third Digital Divide. A Weberian Approach to Digital Inequalities. Routledge. https://doi.org/10.4324/9781315606002

Riddle, C. A. (2020). Why we do not need a 'stronger' social model of disability. Disability \& Society, 35(9), 1509-1513. https://doi.org/10.1080/09687599.2020.1809349

Riddle, C. A. (2020a). Disability and Disadvantage in the Capabilities Approach. In A. Cureton, \& D. Wasserman (Eds.), The Oxford Handbook of Philosophy and Disability (pp. 229-244). Oxford University Press.

Sherbourne, C. D., \& Stewart, A. L. (1991). The MOS social support survey. Social Science \& Medicine, 32(6), 705-714. https://doi.org/10.1016/0277-9536(91)90150-B

Skarstad, K., \& Stein, M. A. (2018). Mainstreaming disability in the United Nations treaty bodies. Journal of Human Rights, 17(1), 1-24. https://doi.org/10.1080/14754835.2017.1286238

Tsatsou, P. (2020). Is digital inclusion fighting disability stigma? Opportunities, barriers, and recommendations. Disability \& Society [early access]. https://doi.org/10.1080/09687599.2020.1749563

Vehmas, S., \& Watson, N. (2014). Moral Wrongs, Disadvantages, and Disability: A Critique of Critical Disability Studies. Disability \& Society, 29(4), 638-650. https://doi.org/10.1080/09687599.2013.831751

Yu, H., Goggin, G., Fisher, K., \& Li, B. (2019). Introduction: disability participation in the digital economy. Information, Communication \& Society, 22(4), 467-472. https://doi.org/10.1080/1369118X.2018.1550525 